\title{
University spaces: Creating cité and place
}

\author{
Paul Temple* - UCL Institute of Education, UK
}

\begin{abstract}
This article examines a number of conceptualizations of interactions between people and physical space, and relates them to university settings to make a link with findings on institutional effectiveness. It argues that the idea of the common-pool resource, where certain physical or social conditions are exploited collectively, is a helpful way of understanding how certain university spaces may be used productively. The opposite situation, the creation of a university 'nonplace', must be guarded against. Planners and institutional managements can support the creation of high-performing spaces managed in common, while allowing students and others to build their own community structures.
\end{abstract}

Keywords: physical space; non-place; common-pool resource; social capital

\section{Introduction}

Richard Sennett, in his book Building and Dwelling (2018), draws on what he tells us is the distinction made in sixteenth-century French usage between cité and ville. The former described urban social life with all its richness and complexities, 'the character of life in a neighbourhood ... and attachments to place' (Sennett, 2018: 1), while the latter referred to physical location and form, the streets and the buildings, and what we would now call infrastructure. As Sennett puts it, 'Today, in New York, traffic jams at the poorly designed tunnels belong to the ville, whereas the rat race driving many New Yorkers to the tunnels at dawn belongs to the cité (ibid.). This distinction between the built environment - the physical form of a town, an institution, a building with its internal and external arrangements - and how people use it, is sometimes presented in terms of the difference between spaces and places. Places are what people may make out of spaces. (See Temple, 2018a, for a summary of the literature on this point.) Sennett uses his chosen terms, though, to present some different perspectives, with cité representing ideas of citizenship and consciousness more broadly, and ville pointing to the 'inner dynamics [of urban forms] ... how buildings relate to one another, or to open space, or to infrastructure' (ibid.: 2). This distinction probes the relationship between people and their surroundings, a point at the heart of this article. Sennett's own examination of these themes goes back to an earlier work presenting a study of medieval Paris (Sennett, 1994: 204), where he argues that the cité and the ville provided together the basis for creating the chartered corporation (the medieval university is an example), allowing the economically important blending of permanence with change to occur.

This article argues that the creation and maintenance of strong cité characteristics, involving high levels of social capital developed around personal interactions with a particular aim in view (for a summary of the theoretical issues about social capital, see Schuller et al., 2000), are the basis of effective universities - which is not to say that ville aspects are unimportant. The two, the physical and the social, the tangible and 
the intangible, are to an extent inevitably interdependent, but need to be planned to achieve working institutional structures. Sennett (2018: 24), describing the work of the great civil engineer Joseph Bazalgette (1819-91) in building London's sewerage system in the mid-nineteenth century, notes how ville infrastructure can profoundly affect how the cite operates; and equally, without the idea-generating, wealthcreating cité, the ville infrastructure would not be built. Although this interaction, once noted, might be considered self-evident, it is striking that - to take the case of higher education - accounts of its built environment often describe in detail architectural styles, external appearances, structural techniques, building materials and so on, with hardly a mention of how all these ville aspects might serve the fundamental cité educational purposes of the institution. Harwood's major study (2015) of postwar English architecture, with an otherwise extremely interesting account of higher education buildings, is an example of this one-sided approach.

I shall draw here on common-pool resource (CPR) theory to help analyse certain university functions. Examples of effective CPRs in operation in many settings may, I shall suggest, be seen in terms of the integration of cité- and ville-type activities and structures, involving high levels of social capital among their users to maximize outputs from the resources in question, and often exhibiting the blend of permanence and change previously noted. The built environment often becomes unsatisfactory for its inhabitants or users - a crime-ridden housing complex, a desolate town centre, an unwelcoming college campus - when ville elements, whatever their intrinsic architectural or technical merits, become ends in themselves, rather than a means towards supporting some wider, broadly agreed, social purpose.

\section{Space and place}

Henri Lefebvre (1991: 33), in his seminal The Production of Space first published in French in 1974, presented what he called the 'conceptual triad', which provides a framework to help understand both the creation and the use of space. While Lefebvre uses various terms to describe the interconnected elements of his triad, it will help us here to use his distinction between 'conceived', 'lived' and 'perceived' space. The conceived, or formally planned, category (which he also calls 'representations of space') could be seen as analogous with Sennett's ville, while the lived category (unhelpfully also labelled by Lefebvre as 'representational space') is similar to the cité. Perceived space, or 'spatial practice', might be thought of as linking the two, in that it reflects 'each member of a given society's relationship to [a particular] space' (ibid.).

A widely held view among writers on this topic is that, as noted in the introduction, interactions between physical forms and the people who inhabit what may be considered to be 'places' within them offer an insight into an important aspect of human experience. Casey (1997: 286), for instance, provides a list of thinkers, including Arendt, Benjamin, Derrida, Foucault and Heidegger, who have 'succeeded in fashioning a fresh face for place'. We are, then, considering a topic that has engaged a succession of important thinkers over the years. Lefebvre's analysis of types of space provides a way of categorizing these human-physical interactions.

Conceived spaces are the (often official or institutional) abstract or conceptual designs that are used to determine and describe space, and to construct it. In a university, these might take the form of campus plans, building design drawings, space planning guidance and signage or design details indicating permissible uses - which will send functional but also symbolic messages about institutional values and priorities (well illustrated in Waite, 2014: 74). These representations are based upon intellectual 
understandings (of architects, engineers and designers), and are also ideologically informed by ideas of how a university should appear (what should a visitor first encounter, and how might they respond?), the ideas its architectural style ought to stimulate in the observer, how organizational hierarchies should be accommodated, the relative importance of different activities and so on. Representations of space can, Lefebvre (1991: 26) argues, point to how ideas can become actions, with space becoming 'a sort of reality of its own ... a means of control'. Thus, the ideas underlying the design of a building lead to the creation and implementation of plans by architects, managers and others in authority. These plans then impose a certain type of order, which may lead to new activities or perceptions - 'realities' - among the users of the building: spaces are never entirely neutral. This technical understanding of space is clearly necessary, but our engagement with it should not stop with the architect's drawings.

We need, additionally, to think about lived spaces, encompassing symbolic values, cultural resonances, and for individuals, beliefs, feelings and memories. These are sometimes oblique, sometimes explicit, and may gain meaning over time. This is the space of imagination, reflection and desire: very much the cité. Lefebvre (ibid.: 39) describes this as 'the passively experienced ... space, which the imagination seeks to change and appropriate'. Lived space also encompasses the concept of 'social history', enabling users of space to construct individual and shared meanings.

Perceived space - perhaps the most original of Lefebvre's categories - is said to be revealed through the daily use of space: the way space is physically used in routine activities, such as walking or meeting others - our spatial practices. Perceived space is material and observable through daily life. In a university, spatial practice might include studying, researching, teaching or socializing, with these activities mostly taking place in predetermined locations. Another study of spatial practices, seeking to 'understand space becoming a place for learning', uses the idea of 'interpersonal metafunction' to examine how users relate to the 'texts' provided by various university spaces, using concepts of power relations, involvement, contact and social distance to consider relations between teachers and students, and between students (Leijon, 2016: 94, 108). This approach is, perhaps, not far distant from Lefebvre's ideas on perceived space. A theorization of urban space uses the term 'transitivity' to capture the idea of 'the city as an everyday process ... flesh and stone in interaction' (Amin and Thrift, 2002: 10), which appears also to have similarities with Lefebvre's (1991: 38) notion of spatial practice focusing on 'daily ... and urban reality ... [with] a certain cohesiveness'. Clearly, these theorizations are all searching for understandings of how people interact with spaces, and with one another in them.

As Whitton (2018) suggests in his study of a large, newly built university academic building, spatial practices are moderated in a university setting by the social relations framed within spaces such as lecture theatres, seminar rooms, staff offices and social areas. The conceived-space design of the building, Whitton (ibid.) argues, following Lefebvre (1991), is intended to create or reinforce a particular set of managementdetermined relationships and ways of being. Over time, the users of spaces establish their spatial practices to enable competences to develop, even if these practices are idiosyncratic and may (or probably will) run counter to managerial intentions. Or, to use Sennett's (2018) categories, it is how the cité appropriates the ville infrastructure.

For Lefebvre (1991), his triad does not represent a fixed state of affairs, but describes a series of ongoing dialectics between conceived, perceived and lived spaces, as these spaces are appropriated and lost. Although there has been considerable interest in Lefebvre's work on analysing socio-spatial relationships, there seem to be only a few examples of its use empirically in analysing educational spaces, 
notably Whitton (2018) and, with a compelling Chinese case study, Zhang (2014) - both of which illustrate tensions between all three triad categories.

I have noted here some ideas that try to capture the complexities involved once we enquire into the interactions of humans with their physical surroundings. How can these ideas be turned to analytical advantage in a university setting?

\section{Space and social capital}

Although evidence has been put forward about the possible role of social capital in supporting the effectiveness of a wide range of organizational and institutional types (by, among many others, Lesser, 2000; Nahapiet and Ghoshal, 1998), the concept seems not to have been widely applied to universities. I have made suggestions (Temple, 2009) about how the creation of social capital may underpin the development of universities as effective sites of knowledge production and transfer - as special places. The idea of social capital supports a deeper analysis of the notion of 'spatial practice', pointing to some of the social processes that may be involved. The particular aspect of social capital theory that I think is relevant here is what has been called 'generalized reciprocity' (Putnam, 2000: 20): that is to say, you might benefit from the activities of others, unknown to you, in creating various social structures and processes without you having personally contributed to this work. You will, though, at some point, probably find yourself being invited to contribute to the shared stock of social capital. Putnam (ibid.: 21) nicely captures this idea with an anecdote about a volunteer fire department in rural America that publicizes its fundraising event with the slogan, 'Come to our breakfast, we'll come to your fire'. The joke works, of course, by subverting the idea of generalized reciprocity - which is in fact the basis on which fire services everywhere are organized.

It is this reciprocity, which we may see as supporting spatial practice, that is so important to effective operations at all levels in knowledge-intensive organizations, from everyday administration to, in universities, the most sophisticated levels of academic collaboration. We may see this as the cite aspect of the university working in practice, distinguished from the university ville, the technocratic aspect of the built environment on which institutional managements typically focus. In doing so, they may overlook the need to help create social capital to support what Martin Trow (2010: 308), describing in the 1960s an almost classical cité or 'lived' purpose, called 'an intellectual milieu ... a group of people who share specific intellectual interests, and who pursue or discuss them together recurrently in special places' - and in so doing drive the university's work forward. This often happens, I suggest, because generalized reciprocity, allowing newer participants to benefit from existing practices, is operating, and, while an intellectual milieu belongs to the cité, Trow (2010) (here and in other writings) does not neglect the 'special place' provided by the ville.

There are good examples of new or refurbished university buildings aiming to meet student and staff needs in imaginative ways, to provide Trow's (2010) 'special places' by creating the human-scale spaces that might support social capital development, often by adapting existing buildings rather than through 'starchitect'designed new build (Coulson et al., 2015: 15). But equally there are instances of institutional managements seemingly intent - although probably unwittingly - on destroying social capital by creating unappealing standardized spaces instead of 'special places' (Cox et al., 2012; Kuntz et al., 2012; Savin-Baden, 2011). This is perhaps surprising, as the cost differences between 'special' and 'ordinary' spaces are likely to be negligible, while the benefits may be considerable. This apparent lack 
of management interest in solving a problem with known solutions is puzzling. But of perhaps even greater concern is an apparent tendency to create 'non-places'.

\section{The problem of the non-place}

The anthropologist Marc Augé (1995), reflecting on the distinction between place and space, suggests a further category of 'non-places' - 'non-lieux' in the original 1992 French edition. His hypothesis is that these are the result of 'two complementary but distinct realities: spaces formed in relation to certain ends (transport, transit, commerce, leisure), and the relations that individuals have with these spaces' (ibid.: 76). (Lefebvre would surely have seen these spaces as special cases of his 'conceived space' classification.) Augé contrasts non-places with 'anthropological places' where 'individual identities ... and the unformulated rules of living know-how' (ibid.: 81) apply. In non-places, by contrast, people have standardized, set identities as passengers, customers and so on, and thus remain anonymous as individuals, with little choice but to obey the formal rules, enforced by formal sanctions, governing the non-place: the airport terminal, the supermarket, the motorway. The social dynamics of the cité find little traction in non-places; nor is there scope for the modest changes usually made by the inhabitants even of highly planned ville environments: Sennett (2018: 234) describes the case of the Eixample district of Barcelona, among others. This anonymity, though, is paradoxically often based on proof of the individual's identity first being presented (an identity card, an airline boarding pass, a credit card, a car registration read by a camera), something not required in relations within traditional, anthropological, places. Augé (1995: 86) points out that language seems to draw a distinction between non-places and places: the motorway intersection as opposed to the crossroads, or the airline passenger (Augé clearly finds air travel anthropologically fascinating), defined by their destination, as opposed to a traveller, who may decide to change their route on a whim.

The university and its students seem to fit quite well with Augé's (ibid.: 76) account of non-places: 'spaces formed in relation to certain ends', with students - and indeed members of staff - obeying a set of rules when in these spaces. The expansion of higher education in many countries has led to more university spaces becoming nonplaces in this sense, rather than Lefebvre's lived spaces, which might be part of the cité. Although Augés non-place examples were designed for their non-place purposes, it seems quite possible for a normal space or place to change (by accident or design) into a non-place: for example, some historic city centres have now been turned over to tourism to such an extent that they have become places almost entirely directed to the 'certain ends' of the heritage industry, rather than to the changing mix of uses and users characteristic of normal cities (I am indebted to Dr Jane Allemano for this observation). Some university places are similarly moving in the non-place direction. Most obviously, student and staff movements are increasingly monitored and controlled by electronic means (security cameras, swipe cards) - even student attendance at lectures is now frequently recorded using ID cards. (There is an irony here in that just when workplace 'clocking-in' has become outmoded in modern businesses, as workers at all levels are given greater autonomy, then universities, where the emphasis was once on individual students' personal responsibilities, are formalizing attendance requirements. Augé might say that, in England at least, this shift is perfectly consistent with government insistence that universities should treat their students as paying customers: as such, they should expect to inhabit university non-places, under constant surveillance, as they do as consumers in other spheres of their lives.) 
But at a deeper level, university spaces may become non-places because their users feel no connection with them or responsibility for them - ultimately, like all nonplaces, they are unloved, always someone else's responsibility, merely 'lived through in the present' by their users, as Augé (ibid.: 84) puts it, but with no further engagement; in other words, pure ville. I shall give here some pointers to how we can try to move university spaces in the opposite direction, to become valued places. But we should note that the non-place concept can be turned to advantage, by using it as a critical lens through which to analyse spaces, to identify missed opportunities within and around buildings (featureless corridors or bleak car parks, perhaps), and then, with a little imagination, to create places that people will wish to use (Nordquist and Fisher, 2018: 210). A project called Social and Informal Learning Spaces at the University of Brighton, UK, sought to identify underused areas on the campus and turn them instead into what the project called 'inspiring spaces', with student input into the design and, for example, 'treating corridors and thoroughfares as significant opportunities to inspire through displays of student-generated work' (Clark and Stanier, 2017: 39, 44). This project was based on the insight that non-places could be turned into places of real value to students.

There is also a related critique around the 'commodification' of public spaces, when what once were, or once might have been, genuine public spaces have become privatized, with a degree of controlled access during defined hours, regulations as to permissible activities with the use of security officers to enforce them, and so on. Where shops once fronted public streets or town squares, they are increasingly found in shopping malls or similarly controlled environments. These developments, it is claimed, reduce 'the opportunities for integration, social interaction and negotiations between various sectors within society' (Williams, 2007: 191). Describing a new development in the King's Cross area of central London, the architectural critic Rowan Moore argues that: 'Developers become de facto mayors and planners, directing the provision of public good. They decide everything from the design of public and private buildings to the management and policing of open space' (Moore, 2018: n.p.). These are perhaps transitional areas between Augé's (1995) non-places and his anthropological places, and are increasingly familiar in campus settings. University visitors may now routinely be stopped by security staff and asked to explain their business on the campus: I was once briefly detained for being unable to account for myself to the security officer's satisfaction.

\section{Creating common-pool resources}

The unappealing non-place does not have to be a university destination. One possibility is to apply the ideas of CPR management, formalized by Nobel laureate Elinor Ostrom (1990), to university spaces. Work in this field shows how resources, both natural and social, tangible and intangible, may be managed collectively in ways that maximize sustainable outputs. Historically, as Ostrom and others have shown, water resources, fisheries and grazing lands have all provided examples of long-lasting CPRs.

A collective approach to the management of both knowledge in the university, and the spaces in which it is produced, drawing on CPR theory, has been considered by a number of writers in recent years (including Johnson and Khoo, 2018; Ostrom and Hess, 2007; Temple, 2018b). In these cases, 'the commons [CPR] paradigm does not look primarily to a system of property, contracts, and markets, but to social norms and rules ... that enable people to share ownership and control of resources' (Bollier, 2007: 29). The use of shared spaces in universities often seems to show that, 
in effect, a CPR is being managed, bringing together, depending on your sociological preferences, ville and cité elements, or conceived and perceived spaces. To revert to our previous discussion, social interactions are usually structured within some kind of physical framework, and these social/physical interactions then need to be managed collectively. We may also note that long-lasting CPRs have been able to achieve a balance between permanence and change, which for Sennett, we saw, required the integration of cité and ville resources.

A number of studies of university libraries - now, significantly, sometimes described as 'learning commons' - have shown how this operates in practice: students seek out learning spaces with particular characteristics, depending on personal preferences, the application of which then influence further use of the spaces. Even when students wish to work individually in the library, they may work:

in close proximity to friends or peers to create a sense of community ... [there is] the feeling of a common purpose. Many learners reported that working in a shared learning environment is motivational. It seems that students are aware of what makes a space feel like a place. Place is about environment, but also about people and what is going on inside. (Harrop and Turpin, 2013: 68)

A common resource is then, in a subtle way, being managed collectively and in the process being changed. In a study from an Australian university, a student reflects on, as the researchers put it, 'the entangled nature of self, social relationships, space, learning ... care for others, and collaborative achievement within a socially engaged supportive environment for learning' (Acton and Halbert, 2018: 5):

If somebody says 'We're in this together', I'll remember that till the end of uni. I'll remember more the group work and the working together than I will [being] at home in my underwear trying to get something done, and I think it's because of the space. Why the space is important to me is because it allows the socialisation to happen, and the socialisation then makes me feel intrinsically motivated to turn up ... we all care about each other and you notice if someone's behind. We make the weakest player as strong as the strongest player ... So the space is really important. I think why it's important is for collaboration. (Ibid.: 6)

The respondent ('We're in this together') might as well have been explaining how a university CPR should work.

Browndorf (2014: 78) similarly reports on a number of studies aimed at 'engendering student feelings of ownership for the library', with the aim of supporting improved student learning. Her claim is that 'psychological ownership positively associates with citizenship behaviors and strength of feelings of responsibility and stewardship ... providing students [with] the ability to work together to craft their own rules over use of a resource may aid in creating feelings of ownership of that resource' (ibid.: 82, 86): an enactment, perhaps, of Lefebvre's (1991) 'perceived' space category. Clark and Stanier (2017) provide further examples of university projects aimed at, in effect, creating spaces to be used as common-pool resources, managed by their users.

Academic and other members of staff may rather similarly benefit from what Nørgård and Bengtsen (2016) have called 'the placeful university'. Here, 'education springs from the interactions and experiences of people and places; from experiences of belonging, dwelling, ownership and responsibility in relation to interactions between university, people and society' (ibid.: 5). Furthermore, the university campus 
'is a site engraved with certain ethical and ideological implications ... [it] is a layout for human experience' (ibid.: 7). That is to say, we need to consider the intellectual cité as well as the ville of the physical campus. But it is essential for the university ville to be an authentic place: for Nørgård and Bengtsen (ibid.: 9), a non-place university is an oxymoron: the university 'is not just a space we occupy in a specific time span during the day ... rather, the university becomes part of our broader lifeworld'. We may also think here of the creation of Lefebvre's (1991) 'perceived' and 'lived' spaces not the planned spaces of architects and designers, but the result of spatial practices, embodying the inhabitants' values and modified by the university's built environment.

CPR theory also offers a perspective on the placeful university. As suggested above, it offers a means of integrating ideas about the ville and the cite - how both tangible and intangible resources may be managed for the benefit of their 'owners' (and, indeed, the wider communities around them). As Nørgård and Bengtsen (2016: 8) put it, 'education at the university is meaningful to the extent that we can be there, dwell in it, have a sense of (co) ownership of it and feel agency in relation to it'. The '(co) ownership' point is crucial here, underlining how CPRs have to be managed cooperatively if the common resource is to be protected.

These ideas take us towards theories about creativity in universities and other knowledge-based organizations, and how creativity may be related to the way space is used. The literature on creativity suggests that certain conditions are conducive to creative work: organizational support, psychological security, a culture appreciating intrinsic motivation, flexible internal arrangements and autonomy in work planning (MacLaren, 2012). Clearly, these conditions are related to organizational cultures rather than to particular physical environments, but they do seem consistent with the ideas of CPR and the 'placeful university'. In both cases, collective responsibility for resources and the ability of users to adapt spaces to their own needs, to feel at home in them, seem likely to support the conditions for creativity noted here. While creativity requires ville organizational structures, it is essentially a product of the cité.

It may be objected at this point that firm empirical evidence on all the points noted here is absent, and that, while admittedly it might be difficult to obtain, it should not be impossible to do so. A research project comparing learning outcomes under different space management regimes, for example, would be difficult to design and to administer, and its findings would no doubt be open to challenge - but that is in the nature of much social science research. I suggest that research on these lines perhaps following some of Ostrom's methodologies (she did, after all, win a Nobel Prize) - could potentially produce findings that would be of considerable theoretical and operational value.

\section{The university at work: Bringing the tangible and intangible together}

I have noted here a number of conceptual approaches aimed at understanding human interactions with the built environment, and the special issues arising when university spaces, involving knowledge production and transmission, requiring shared pools of knowledge, are involved. What we can derive from these approaches, I propose, are ways of better understanding universities as social entities, each in its particular physical setting, providing the permanence and yet the possibility of change, noted earlier in Sennett's (2018) writing. The significance, incidentally, which I am claiming for this interaction between the physical and the social, the tangible and the intangible, explains at least in part why distance-learning universities - and we now have over 
half-a-century's worth of global experience to draw on - have struggled to achieve the impacts that their promoters have usually confidently anticipated. They have not necessarily failed - although some have - but they have hardly slowed the growth of physical universities, as a glance at Coulson et al.'s (2015) summary of just some of the various large-scale, costly campus developments taking place around the world will confirm. As these writers observe, 'The idea of a university education is inviolably associated with the idea of place' (ibid.: 10) - at least, it has been so far. Similarly, the idea of the 'placeful university', noted above, requires a 'layout for human experience' that will be hard to replicate in a non-physical setting. (Some may perhaps claim that the ultra-realistic settings created in some current video games, together with Algenerated interactions, may help here, although special effects do not make up for the lack of genuine human encounters.)

I am arguing here that the physical university ville and its conceived spaces, and the intellectual work of the university cité with its perceived and lived spaces, need to be planned together, and not allowed to drift apart. Non-places need to be changed into real places, which may become perceived, special places, supporting valued activities of different kinds, but ones that support the development of social capital and so high-quality intellectual work. Then, perhaps, a CPR will have been created, leading to social and intellectual benefits that spread across the university.

Table 1 is an attempt to classify characteristics of the types of spaces I have considered here.

Table 1: Characteristics of types of spaces

\begin{tabular}{|c|c|c|c|c|}
\hline & Ordinary space & Non-place & Special place & CPR place \\
\hline $\begin{array}{l}\text { Lefebvre (1991) } \\
\text { triad category }\end{array}$ & $\begin{array}{l}\text { 'Conceived'/ } \\
\text { 'Lived' }\end{array}$ & 'Conceived' & 'Lived' & 'Spatial practice' \\
\hline $\begin{array}{l}\text { Availability to } \\
\text { users }\end{array}$ & Variable & $\begin{array}{l}\text { Controlled } \\
\text { access }\end{array}$ & $\begin{array}{l}\text { Ready or shared } \\
\text { access }\end{array}$ & $\begin{array}{l}\text { Ready or shared } \\
\text { access }\end{array}$ \\
\hline $\begin{array}{l}\text { Mode of } \\
\text { management }\end{array}$ & Formal & Formal & Informal & Cooperative \\
\hline Qualities & Variable & Fixed & User-affected & $\begin{array}{l}\text { Defined by } \\
\text { purpose }\end{array}$ \\
\hline $\begin{array}{l}\text { Social capital } \\
\text { possibilities }\end{array}$ & $\begin{array}{l}\text { Variable } \\
\text { reciprocity }\end{array}$ & $\begin{array}{l}\text { Low to zero } \\
\text { reciprocity }\end{array}$ & $\begin{array}{l}\text { Generalized } \\
\text { reciprocity }\end{array}$ & $\begin{array}{l}\text { Reciprocity } \\
\text { among members }\end{array}$ \\
\hline
\end{tabular}

What should university managements conclude from this? The aim, I suggest, should be to move as many spaces as possible in the university from the left towards the two right-hand columns of Table 1 . This will probably mean finding out more about which spaces in the institution are valued by staff and students, and why. This is more difficult than it may appear at first sight: the question is rarely addressed even in the limited quantity of literature on space and place in higher education. One writer, discussing the idea of an 'ambiently sociable setting', where users of university space are involved in 'a variety of intermittent exchanges, serendipitous encounters and apparently solitary study' (Bligh, 2014: 41) - reminding us of the library-based studies noted earlier - suggests that museums have made greater efforts than universities to make links between space design and users' needs. This may now be changing, however. A recent empirical study encouraged students and teachers to critique and redesign a prototype learning space so that it better met their learning needs - a process that, it 
is reported, caused participants to reflect more deeply on the pedagogy taking place there (Casanova et al., 2018). Leijon (2016) has, as noted earlier, studied how both teachers and students understand the 'text' of a teaching room, and how the room's layout - its spatial pedagogy - can affect the learning that goes on in it.

What are easy to find are studies that suggest that student learning will be improved with, for example, open-plan, flexible workspaces with comfortable furniture and inspiring design, which 'should present a ... vision of functionality, sophistication and creativity' (Sinclair, 2007: n.p.). While suggestions like this are not to be dismissed, they pose several problems. One is that ideas about 'sophistication' and 'inspiring design' are likely to differ culturally, generationally and in other ways; another is that designing-in 'creativity', when creativity is presumably supposed to be an output, seems to be getting things back-to-front. If we really knew how to 'present a vision of creativity', then using it to design student workspaces would be a minor benefit. A better approach, perhaps, is to adopt a bottom-up method, rather than one that assumes that management or designers know best about what works for diverse groups of users. So the place that the students at Zhejiang University struggled to preserve met their particular needs (Zhang, 2014); as did the very different building at a US campus reported by Kuntz et al. (2012); as did the accommodation at Berkeley, described by Trow in the 1960s (Trow, 2010); as did the Australian workspace in Acton and Halbert's (2018) study. The classification of 'special places' and 'CPR places' in Table 1 is intended to indicate that they are user-determined places, rather than ones imposed on users - even with the most benign intentions - from above.

That is not to say that the creation of 'special places' may be left entirely in the hands of their users. A study of a facility at a UK university intended to use design features to enhance student learning found that its student users valued the 'sense of place' it offered, in contrast to being 'transient ... nomadic and detached from any sense of being part of a collective' (Boddington, 2011: 181). The design features, it seems, allowed students to take ownership of spaces. A broader perspective on providing user-determined spaces is given in this account of the design philosophy of the University of York (UK) from the early 1960s:

these spatial features of York - the collegiate arrangements, the loose groupings of buildings in nature with many interconnecting paths, and the incipient aesthetic of mystery - were intended to generate a particular relationship between the student and his or her environs, a freedom from restraint and an opportunity to cultivate selfhood ... at York the individual was to develop as a whole in his or her endeavor of private and shared discovery, the intellectual exploration symbolised by the physical ... [they] can experience the campus as a place in its own right, with its own history and meanings, have the opportunity of finding their own part in a community and in a tradition - of participating in the idea of the university. (Ossa-Richardson, 2014: 152, 154)

\section{Conclusions}

Introducing his major study of post-war university architecture and design, Stefan Muthesius (2000: 2) suggests that: "The way in which "architecture" does matter to most users of a university is the way it is wedded to its institutionality' - in other words, how it helps the university to function effectively. This article has attempted to look at learning in the university once the architects have left, to see how the use of the spaces 
they have provided may also contribute to its institutionality - to its effectiveness as a university.

We have seen that a variety of thinkers have considered how a physical framework provided by what Sennett (2018) calls the ville allows the social and intellectual cité to develop within it, through the creation of special places. Lefebvre, while drawing broadly similar distinctions, argues that spaces may be designed to ensure a particular form of cité development - although it seems questionable whether in universities the directive methods that Lefebvre indicates will achieve their intended results. Instead, high-functioning university spaces may, I propose, be analysed in terms of CPR theory, studying their effectiveness by reference to both suitable physical design features and the generation within them of social capital. This approach to space analysis seems to fit with what we know about supporting creativity and, equally importantly, it is what the users of such spaces tell us they want.

Unusually for a management challenge in higher education, what needs to be done to create CPR-type spaces lies almost wholly within institutional managers' powers. If this is not the single most important thing that they should do, it is difficult to believe that it should be the least important.

\section{Notes on the contributors}

Paul Temple is Reader Emeritus in Higher Education at the UCL Institute of Education in London, where he was until recently Co-Director of its Centre for Higher Education Studies. His books include the edited volume The Physical University: Contours of space and place in higher education (Routledge, 2014) and The Hallmark University: Distinctiveness in higher education management (UCL IOE Press, 2014). He is the joint author of the Oxford Very Short Introduction to Universities and Colleges (Oxford University Press, 2017).

\section{References}

Acton, R. and Halbert, K. (2018) 'Enacting learning citizenship: A sociomaterial analysis of reflectivity and knowledge negotiation in higher education'. Reflective Practice, 19 (5), 707-20.

Amin, A. and Thrift, N. (2002) Cities: Reimagining the urban. Cambridge: Polity Press.

Augé, M. (1995) Non-Places: Introduction to an anthropology of supermodernity. Trans. Howe, J. London: Verso.

Bligh, B. (2014) 'Examining new processes for learning space design'. In Temple, P. (ed.) The Physical University: Contours of space and place in higher education. London: Routledge, 34-57.

Boddington, A. (2011) 'Designing education and reshaping learning'. In Boddington, A. and Boys, J. (eds) Re-Shaping Learning: A critical reader: The future of learning spaces in post-compulsory education. Rotterdam: Sense Publishers, 179-91.

Bollier, D. (2007) 'The growth of the commons paradigm'. In Hess, C. and Ostrom, E. (eds) Understanding Knowledge as a Commons: From theory to practice. Cambridge, MA: MIT Press, 27-40.

Browndorf, M. (2014) 'Student library ownership and building the communicative commons'. Journal of Library Administration, 54 (2), 77-93.

Casanova, D., Di Napoli, R. and Leijon, M. (2018) 'Which space? Whose space? An experience in involving students and teachers in space design'. Teaching in Higher Education, 23 (4), 488-503.

Casey, E.S. (1997) The Fate of Place: A philosophical history. Berkeley: University of California Press.

Clark, M. and Stanier, S. (2017) 'Spaces that inspire'. In University Alliance Technical and Professional Excellence: Perspectives on learning and teaching. London: University Alliance, 39-45.

Coulson, J., Roberts, P. and Taylor, I. (2015) University Trends: Contemporary campus design. London: Routledge.

Cox, A., Herrick, T. and Keating, P. (2012) 'Accommodations: Staff identity and university space'. Teaching in Higher Education, 17 (6), 697-709. 
Harrop, D. and Turpin, B. (2013) 'A study exploring learners' informal learning space behaviors, attitudes, and preferences'. New Review of Academic Librarianship, 19 (1), 58-77.

Harwood, E. (2015) Space, Hope and Brutalism: English architecture, 1945-1975. New Haven, CT: Yale University Press.

Johnson, W.M. and Khoo, M.J. (2018) 'Analysing the learning commons in the digital age'. In Ellis, R.A. and Goodyear, P. (eds) Spaces of Teaching and Learning: Integrating perspectives on research and practice. Singapore: Springer, 105-28.

Kuntz, A.M., Petrovic, J.E. and Ginocchio, L. (2012) 'A changing sense of place: A case study of academic culture and the built environment'. Higher Education Policy, 25 (4), 433-51.

Lefebvre, H. (1991) The Production of Space. Trans. Nicholson-Smith, D. Oxford: Blackwell.

Leijon, M. (2016) 'Space as designs for and in learning: Investigating the interplay between space, interaction and learning sequences in higher education'. Visual Communication, 15 (1), 93-124.

Lesser, E.L. (2000) 'Leveraging social capital in organizations'. In Lesser, E.L. (ed.) Knowledge and Social Capital: Foundations and applications. Boston: Butterworth-Heinemann, 3-16.

MacLaren, I. (2012) 'The contradictions of policy and practice: Creativity in higher education'. London Review of Education, 10 (2), 159-72.

Moore, R. (2018) 'Thomas Heatherwick's Coal Drops Yard - shopping in the Instagram age'. The Observer, 3 November. Online. https://tinyurl.com/y9l8zrhn (accessed 5 April 2019).

Muthesius, S. (2000) The Postwar University: Utopianist campus and college. New Haven, CT: Yale University Press.

Nahapiet, J. and Ghoshal, S. (1998) 'Social capital, intellectual capital, and the organizational advantage'. Academy of Management Review, 23 (2), 242-66.

Nordquist, J. and Fisher, K. (2018) 'The missing link: Aligning blended curricula with physical learning spaces in health interprofessional education'. In Ellis, R.A. and Goodyear, P. (eds) Spaces of Teaching and Learning: Integrating perspectives on research and practice. Singapore: Springer, 195-220.

Nørgård, R.T. and Bengtsen, S.S.E. (2016) 'Academic citizenship beyond the campus: A call for the placeful university'. Higher Education Research and Development, 35 (1), 4-16.

Ossa-Richardson, A. (2014) 'The idea of a university and its concrete form'. In Temple, P. (ed.) The Physical University: Contours of space and place in higher education. London: Routledge, 131-58.

Ostrom, E. (1990) Governing the Commons: The evolution of institutions for collective action. Cambridge: Cambridge University Press.

Ostrom, E. and Hess, C. (2007) 'A framework for analyzing the knowledge commons'. In Hess, C. and Ostrom, E. (eds) Understanding Knowledge as a Commons: From theory to practice. Cambridge, MA: MIT Press, 41-82.

Putnam, R.D. (2000) Bowling Alone: The collapse and revival of American community. New York: Simon and Schuster.

Savin-Baden, M. (2011) 'Research spaces'. In Boddington, A. and Boys, J. (eds) Re-Shaping Learning: A critical reader: The future of learning spaces in post-compulsory education. Rotterdam: Sense Publishers, 93-103.

Schuller, T., Baron, S. and Field, J. (2000) 'Social capital: A review and critique'. In Baron, S., Field, J. and Schuller, T. (eds) Social Capital: Critical perspectives. Oxford: Oxford University Press, 1-38.

Sennett, R. (1994) Flesh and Stone: The body and the city in Western civilization. London: Faber and Faber.

Sennett, R. (2018) Building and Dwelling: Ethics for the city. London: Allen Lane.

Sinclair, B. (2007) 'Commons 2.0: Library spaces designed for collaborative learning'. Educause Quarterly, 30 (4), 4-6.

Temple, P. (2009) 'From space to place: University performance and its built environment'. Higher Education Policy, 22 (2), 209-23.

Temple, P. (2018a) 'Space, place and institutional effectiveness in higher education'. Policy Reviews in Higher Education, 2 (2), 133-50.

Temple, P. (2018b) 'Space, place and university society: Insights from common-pool resource theory'. In Ellis, R.A. and Goodyear, P. (eds) Spaces of Teaching and Learning: Integrating perspectives on research and practice. Singapore: Springer, 31-45.

Trow, M. (2010) 'The campus as a context for learning: Notes on education and architecture'. In Trow, M. Twentieth-Century Higher Education: Elite to mass to universal. Ed. Burrage, M. Baltimore, MD: Johns Hopkins University Press, 301-18.

Waite, P. (2014) 'Reading campus landscapes'. In Temple, P. (ed.) The Physical University: Contours of space and place in higher education. London: Routledge, 72-83. 
Whitton, P.D. (2018) 'The New University: Space, place and identity'. Unpublished PhD thesis, Manchester Metropolitan University.

Williams, T. (2007) 'Rationalising public place commodification and the ramifications of this choice in Alberta, Canada'. In Osborne, M., Sankey, K. and Wilson, B. (eds) Social Capital, Lifelong Learning and the Management of Place. London: Routledge, 190-200.

Zhang, Z. (2014) '"Let's go for the chicken-drum": The everyday production of social space in a Chinese university'. In Temple, P. (ed.) The Physical University: Contours of space and place in higher education. London: Routledge, 182-202. 